\title{
Antifertility Effect of Some Plant Leaf Extracts on the Prolific Breeding of Oreochromis Niloticus
}

\author{
Obaroh, I. 0. \\ Department of Biological Sciences, \\ Kebbi State University of Science and Technology \\ Aliero, Kebbi State, Nigeria \\ Nzeh, G. C. \\ Department of Zoology, University of Ilorin, \\ P.M.B 1515 Ilorin, Kwara State, Nigeria
}

\section{Doi:10.5901/ajis.2013.v2n12p87}

\begin{abstract}
The major problem in tilapia culture is in their prolific breeding habit; which usually results into over-population in the culture system thus leading to stunted growth. Effect of crude extracts of Azadirachta indica, Psidium guajava and Mangifera indica leaf on reproduction of Oreochromis niloticus was investigated. One hundred and eighty fish (per plant leaf extract) of approximately the same mean weight were grouped into 6 (Represented as; D1, D2, D3, D4, D5 and D6) and stocked in out-door concrete tanks. Fish were fed 3\% of their body weight for 56 days with basal diet (35\% crude protein) containing varying concentrations (0.0, 0.5, 1.0, 2.0, 4.0 and $8.0 \mathrm{gkgl}$ ) of the leaf extracts. There was significant difference $(p \leq 0.05)$ in the hatchling counts of Oreochromis niloticus fed crude extract of $A$. indica and $M$. indica with complete inhibit on reproduction at 1.0 and $2.0 \mathrm{gkgl}$. Hatchling counts of crude extract of $P$. guajava leaf showed no significant difference $(p \geq 0.05)$, thought gradual decrease in the hatchling counts were observed as the concentration of the leaf extract in the diets increases. This infers that $A$. indica and $M$. indica could be used effectively to control prolific breeding associated with tilapia culture.
\end{abstract}

Keywords: Prolific, breeding, concentrations, plant extracts, culture.

\section{Introduction}

Tilapia, an African freshwater fish belong to the family Cichlidae with over 100 species. Culture of tilapia could be found across most countries of he world (Balarin and Hatton 1979), this is because they possess attributes that makes it suitable for culture amongst which are; high tolerance to environmental conditions, ability to withstand wide range of salinity, converts food efficiently and high yield potentials (Ridha, 2006). Tilapia culture is however fraught with the problem of prolific breeding which usually lead to over population in the culture system and stunting in growth of the fish species. Oreochromis niloticus had been reported to reach sexual maturity at about $20 \mathrm{~g}$ of body weight, breeding in small size in tilapia had also been observed to divert energy from growth into reproduction which involves territorial/courtship behavior and the metabolic cost of gametes formation. Furthermore the progeny produced by the stocked fish compete for available space and food resources, thereby limiting the growth of the stocked fish, especial in ponds where space and food quickly becomes limiting (Mairs and Little 1991).

For efficient and sustainable development of tilapia culture, the prolific breeding needs to be reduced or stopped. The various methods that had been used to controlling reproduction in tilapia 
includes; intermittent harvest, high density effect, manual sexing, use of predators, cage culture, sterility and hybridization (Mairs and Little 1991) are not without their shortfalls; for example wide spread adoption of hybridization had been found to possibly lead to introgression of tilapia species with deleterious implications for the conservation of tilapia genetic resources, hormonal sex reversal had been observed to have negative effects on human health, furthermore its use had been prohibited in some countries of the world, while achieving $100 \%$ manual sexing had been found not to be possible, thus the need to search for alternative.

Several plant materials had been reported to possess properties that prevent conception when administered orally amongst which are; Jatropas curcas, Carica papaya, Azadirachta indica, Psidium guajava, Curcuma longa, Gossypium herbaceium, Dioscora esculenta, Mangifera indica etc., (Bodhankar, et al., 1974; Lohiya and Goyal, 1992; Goonasekera, et al., 1995; Purohit and Daradka, 1999; McNeil et al., 2003 and Aliyu, 2007), most of these herbs were observed to have interfered with normal sperm production or motility. Antifertility drugs usually act as antiimplantation, abortifacient, antizygotic, blastocystoxic, postcoital antifertility, antiandrogenic or antispermatogenic agent when administered orally thus, suppressing or inhibiting reproduction. Azadirachta indica is an evergreen tree, with densed crown, the leaves which are globrous are divided into leaflets, matured leaf is asymmetric with dentate margins except for the base of the basicopal half, which is strongly reduced and cuneate or wedged shaped (Bokhari and Aslam, 1985). Mangifera indica tree has simple alternate evergreen leaf, they are dark green when matured (Wikipedia.org). Psidium guajava is a low evergreen tree or shrub with wide- spreading branches and square downy twigs (Ayensu, 1978), the leaf is aromatic when crushed.

Extract of $A$. indica leaf have been reported to cause sterility in rats (Dixit et al., 1992; Shaikh et al., 1993; Khillare and Shrivastav 2003), extract of Mangifera indica leaf was observed to reduce the number of litter in rats (Ibraheem et al., 2007). Extract of Psidium guajava leaf had also been reported to possess antiimplantation substance in white mice (Sri Retno et al., 2008), there are few report on the effects of these plant extracts on the reproduction of Oreochromis niloticus (Obaroh and Nzeh, 2010; Obaroh and Achionye-Nzeh, 2011, 2012). The use of plant extract could be a possible solution that could be used to control prolific breeding in 0 . niloticus.

\section{Materials and Methods}

\subsection{Study Locations}

The study was carried out at the Hatchery Farm of Ministry of Agriculture and Natural Resources, Ilorin, Kwara State. It is on the latitude $8^{\circ} 30^{\prime} \mathrm{N}$ and longitude $4^{\circ} 23^{\prime} \mathrm{E}$.

\subsection{Acquisition of Fish}

Oreochromis niloticus for this research work were obtained from the Hatchery Farm of Ministry of Agriculture and Natural Resources, Ilorin, Kwara State.

\subsection{Extraction of Plant Leaf}

The fresh plant leaf of Azadirachta indica, Mangifera indica and Psidium guajava obtained within Ilorin metropolis, were authenticated in the herbarium section of the Department of Plant Biology, University of Ilorin, Kwara state. The plant leaf were shade dried for two weeks before grinding with a blender, $100 \mathrm{~g}$ of ground leaf was soaked in $500 \mathrm{ml}$ ethanol for 24 hours with constant shaking at intervals as described by Musa et al., (2000). It was filtered using Watman filter paper, the filtrate was concentrated by drying it in the oven at a temperature of $40^{\circ} \mathrm{C}$ for 8 hours it was then left open for several days to obtain a jelly-like extract. The concentrated jelly-like extract was stored in clean bottle, labeled and then preserved in the refrigerator until when needed. 


\subsection{Preparation of Experimental Diets}

A basal diet containing $35 \%$ crude protein was prepared with the following ingredients; Yellow maize, Groundnut cake, Soybean meal, Fish meal, Blood meal, Cassava starch (binder), Methionine and Vitamin/Mineral premix. All ingredients were weighed and hand mixed in a bowl after which, each of the inclusion levels $(0.0,0.5,1.0,2.0,4.0$ and $8.0 \mathrm{~g})$ of the plant extracts were also weighed, and then mixed separately with $1 \mathrm{~kg}$ of the basal diet as reported by Dada and Ikuerowo (2009) with little modification. The experimental diets were further mixed in a Hobbart A-200T pelleting/mixing machine, hot water was added at interval to gelatinize the starch. All the 6 diets were pelletized with a die of $2 \mathrm{~mm}$ in diameter, they were further air dried, kept in labeled cellophane bags and stored in the refrigerator.

\subsection{Experimental Design}

A total of 180 Oreochromis niloticus juveniles (for each set-up, 4 set-up altogether making a total of 720 0. niloticus) were divided into 6 groups representing the treatments (D1, D2, D3, D4, D5 and D6, with D1 representing the control). Each group was further divided into 3 to give a total of 18 replicates consisting 10 fishes per replicate, 5 males and 5 females according to Ekanem and Okoronkwo (2003). Each group of 10 fishes were stocked in outdoor concrete tanks $(2 \times 2 \times 1.25 \mathrm{~m})$ supplied with 450 litres of water (Plate 5). The fish were fed $3 \%$ of their body weight, $1.5 \%$ between the hours of $0800-0900 \mathrm{~h}$ and $1.5 \%$ between the hours of $1600-1700 \mathrm{~h}$. Diet ratio were adjusted based on the weight obtained weekly. Water in each tank were replaced weekly. The same experimental design was used for each of the plant extracts administered independently at various times ( 3 set-up altogether). The study lasted for 24 weeks with each set up having 8 weeks per plant.

\subsection{Determination of Dissolved Oxygen, Temperature and $\mathrm{pH}$}

The dissolved oxygen, temperature and $\mathrm{pH}$ of the water in tanks were determined bi-weekly viz:

\subsubsection{Temperature}

The water temperature was taken using mercury-in-glass thermometer. By dipping the thermometer to about $10-15 \mathrm{~cm}$ depth, the reading was taken at the point where the mercury thread became static.

\section{$2.6 .2 \mathrm{pH}$}

The water $\mathrm{pH}$ was determined using $\mathrm{pH}$ meter, before use the $\mathrm{pH}$ was standardized using $\mathrm{pH} 4,7$ and 9 buffer solutions. Water samples from the 6 groups were collected in clean labeled reagent bottles, $60 \mathrm{ml}$ of the water was measured into a clean beaker, the probe was then dipped into the water, the reading was recorded when a steady figure was obtained. Each time a sample was determined the probe was dipped into distilled water and wiped clean before reusing again.

\subsubsection{Dissolved oxygen}

The dissolved oxygen in the water was determined by the Winkler's method as described by Boyd (1981). Water sample from each tank were collected using a glass stopper bottle, the bottle was dipped completely in water by avoiding contact with air, it was completely filled and the stopper replaced, immediately $1 \mathrm{ml}$ of Manganese sulfate solution was added just below the water surface by using a pipette, $1 \mathrm{ml}$ of alkaline potassium iodide solution was also added in similar manner. The 
stopper was inserted and the bottle was inverted several times to mix the content, the precipitate formed was allowed to settle half way before mixing again, $1 \mathrm{ml}$ of concentrated hydrogen tetraoxosulphate $\mathrm{VI}$ acid $\left(\mathrm{H}_{2} \mathrm{SO}_{4}\right)$ was added and shaken severally, all these were done at the concrete tanks site before the water samples were taken to the laboratory for further analysis. The samples were brought into the laboratory and allowed to settled for 5 minutes, $100 \mathrm{ml}$ of the sample was measured and poured into a conical flask, immediately it was titrated with $0.025 \mathrm{~N}$ of freshly prepared sodium thiosulfate solution to a pale straw colour, $1 \mathrm{ml}$ of starch solution was added resulting into a blue colour, the titration was continued until the blue colour just disappeared. The concentration of the dissolved oxygen in the water sample is equivalent to the number of millitres of titrant used, thus the total number of milliliters of titrant used before and after adding the starch solution equals the total dissolved oxygen in the sample in $\mathrm{mg} / \mathrm{L}$.

\subsection{Statistical Analysis}

The data obtained were analyzed using SPSS 18.0 a statistical software package for mean, standard deviation and one-way ANOVA. Duncan's Multiple Range Test was used to test for significant differences among the means, and Student's t-test to test between two independent observations. The bar charts were determined using Excel.

\section{Results}

\subsection{Ingredients and Percentage Crude Protein Composition of Experimental}

Table la shows the ingredient composition of the basal diet obtained locally. Table $1 \mathrm{~b}$ presents the percentage crude protein of the experimental diets incorporated with different concentrations of the $A$. indica, $M$. indica and $P$. guajava leaf extract, the three plant extracts at different concentrations were observed not to have significant effect on the percentage crude protein of the experimental diets.

Table 1a: Ingredients Composition of Basal Diet

\begin{tabular}{lcccccc}
\hline \multirow{2}{*}{ Ingredient } & \multicolumn{7}{c}{ Treatments } \\
\cline { 2 - 7 } & D1 & D2 & D3 & D4 & D5 & D6 \\
\hline & 0.0 & 0.5 & 1.0 & 2.0 & 4.0 & 8.0 \\
Plant extract & 30 & 30 & 30 & 30 & 30 & 30 \\
Fish meal & 25 & 25 & 25 & 25 & 25 & 25 \\
Yellow maize & 20 & 20 & 20 & 20 & 20 & 20 \\
Soybean meal & 10 & 10 & 10 & 10 & 10 & 10 \\
Blood meal & 8 & 8 & 8 & 8 & 8 & 8 \\
Groundnut cake & 3 & 3 & 3 & 3 & 3 & 3 \\
Vit/min premix & 2 & 2 & 2 & 2 & 2 & 2 \\
Methionine & 2 & 2 & 2 & 2 & 2 & 2 \\
Cassava starch & 2 & & & & & \\
\hline
\end{tabular}


Table 1b: Percentage Crude Protein Composition of Experimental Diets

\begin{tabular}{lcccccc}
\hline & \multicolumn{6}{c}{ Treatments } \\
\cline { 2 - 7 } & D1 & D2 & D3 & D4 & D5 & D6 \\
Plant & $\left(0.0 \mathrm{gkg}^{-1}\right)$ & $\left(0.5 \mathrm{gkg}^{-1}\right)$ & $\left(1.0 \mathrm{gkg}^{-1}\right)$ & $\left(2.0 \mathrm{gkg}^{-1}\right)$ & $\left(4.0 \mathrm{gkg}^{-1}\right)$ & $\left(8.0 \mathrm{gkg}^{-1}\right)$ \\
\hline Azadirachta indica & $35.23 \pm 0.44$ & $35.14 \pm 0.39$ & $34.78 \pm 1.01$ & $35.01 \pm 0.63$ & $35.17 \pm 0.33$ & $35.33 \pm 0.71$ \\
Mangifera indica & $34.55 \pm 0.97$ & $34.81 \pm 0.83$ & $35.07 \pm 0.06$ & $35.11 \pm 0.26$ & $34.67 \pm 0.79$ & $35.12 \pm 0.22$ \\
Psidium guajava & $35.04 \pm 0.66$ & $35.17 \pm 0.19$ & $34.98 \pm 0.66$ & $35.08 \pm 0.04$ & $35.00 \pm 0.31$ & $35.31 \pm 0.11$ \\
\hline
\end{tabular}

\subsection{Hatchling Count of $O$. niloticus fed Crude Extract of $A$. indica, M. indica and P. guajava}

Table 2 shows the hatchling counts of $O$. niloticus fed crude extracts of $A$. indica, $M$. indica and $P$. guajava at varying concentrations. In the fish species fed varying concentration of $A$. indica, the control group (D1) bred twice with the highest hatchling count of 303-398 in the $3^{\text {rd }}$ week and 6389 in the $5^{\text {th }}$ week; group fed $0.5 \mathrm{gkg}^{-1}$ (D2) $A$. indica leaf also bred twice with 178-233 hatchling count in the $6^{\text {th }}$ week and $35-51$ hatchlings count in the $7^{\text {th }}$ week. There was no breeding in groups D3, D4, D5 and D6 respectively.

In the group of fish species fed varying concentrations of crude extract of $M$. indica leaf, three groups including the control (D1) spawned, the control group spawned twice with the highest hatchling count of 248-308 in the $2^{\text {nd }}$ week and 47-66 in the $4^{\text {th }}$ week, while least hatchling counts were observed in group fed $1.0 \mathrm{gkg}^{-1}$ (D3) with 73-98 hatchling count, Fish fed varying concentrations of crude extract of $P$. guajava was observed to breed through out the groups, highest hatchling count was observed in the group fed $0.0 \mathrm{gkg}^{-1}$ (D1) with $357-413$ hatchling counts, while the lowest count was observed in group fed $8.0 \mathrm{gkg}^{-1}$ (D6) with 311-359 hatchling counts. All the groups spawned twice with the exception of groups D3 and D6.

Statistical analysis of the hatchling counts in groups fed varying concentrations of $A$. indica and $M$. indica showed significant difference $(p \leq 0.05)$ between each the groups, there was no significant difference $(p \geq 0.05$ ) in the hatchling counts of fish fed crude extract of $P$. guajava. Gradual decrease in hatchling counts were observed as the concentrations of the three plant leaf extracts increase.

\subsection{Physico-chemical Parameters of water in Tanks used for Culture}

Table 3 presents some physic-chemical parameters of water in tanks used for culture of 0 . niloticus fed varying concentrations of crude extracts of $A$. indica, $M$. indica and $P$. guajava leaf. In fish group fed varying concentrations of $A$. indica leaf extract, the highest dissolved oxygen, temperature and $\mathrm{pH}(5.65 \pm 0.25 \mathrm{mg} / \mathrm{L}, 28.50 \pm 0.50 \stackrel{\circ}{ } \mathrm{C}$ and $7.70 \pm 0.05)$ were observed in group fed $0.0,0.5$ and $8.0 \mathrm{~g} \mathrm{~kg}^{-1}$ diets respectively (D1, D2 and D6), while the least $(5.00 \pm 0.06 \mathrm{mg} / \mathrm{L}$, $27.00 \pm 1.00 \subseteq \mathrm{C}$ and $7.51 \pm 0.03)$ were observed in groups fed $8.0,1.0$ and $8.0 \mathrm{gkg}^{-1}$ diets respectively (D6, D3 and D6). In the group of fish fed varying concentrations of $M$. indica leaf extract, the highest dissolved oxygen, temperature and $\mathrm{pH}(5.75 \pm 0.76 \mathrm{mg} / \mathrm{L}, 28.33 \pm 0.58 \cong \mathrm{C}$ and $7.69 \pm 0.04)$ were observed in groups fed $4.0,0.5$ and $8.0 \mathrm{~g} \mathrm{~kg}^{-1}$ diets respectively (D5, D2 and D6),

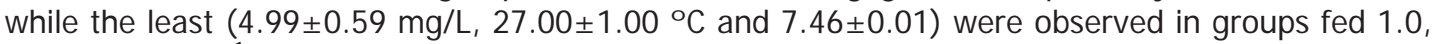
0.0 and D4 $\mathrm{gkg}^{-1}$ diets respectively (D3, D1 and D4). In the group of fish fed varying concentrations $P$. guajava leaf extract, the highest dissolved oxygen, temperature and $\mathrm{pH}(5.70 \pm 0.23 \mathrm{mg} / \mathrm{L}$, $27.17 \pm 0.76 \stackrel{\circ}{ } \mathrm{C}$ and $7.60 \pm 0.03)$ were observed in groups fed $8.0,0.5$ and $8.0 \mathrm{gkg}^{-1}$ diets respectively (D6, D2 and D6), while the lowest $(5.25 \pm 0.05 \mathrm{mg} / \mathrm{L}, 28.50 \pm 0.50 \stackrel{\circ}{ } \mathrm{C}$ and $7.42 \pm 0.25$ ) were observed in groups fed 2.0, 4.0 and $0.0 \mathrm{gkg}^{-1}$ diets respectively (D4, D5 and D1).

Statistical analysis of the mean values of dissolved oxygen, temperature and $\mathrm{pH}$ showed no significant difference $(p \geq 0.05)$ within the groups except the $\mathrm{pH}((\mathrm{p} \leq 0.05))$ of water in tanks used 
to culture fish fed with varying concentrations of crude extracts of $M$. indica and $P$. guajava leaf.

Table 3: Hatchling Counts of O. niloticus fed crude extract $A$. indica, M. indica and $P$. guajava

\begin{tabular}{|c|c|c|c|c|c|c|c|c|c|}
\hline \multirow[b]{2}{*}{ Groups/Concns } & \multicolumn{3}{|c|}{ Azadirachta indica } & \multicolumn{3}{|c|}{ Mangifera indica } & \multicolumn{3}{|c|}{ Psidium guajava } \\
\hline & Range & Mean & $\begin{array}{c}\text { Period } \\
\text { (wk) }\end{array}$ & Range & Mean & $\begin{array}{c}\text { Period } \\
\text { (wk) }\end{array}$ & Range & Mean & $\begin{array}{l}\text { Period } \\
\text { (wk) }\end{array}$ \\
\hline D1 $\left(0.0 \mathrm{gkg}^{-1}\right)$ & $303-398$ & $349.67 \pm 47.52^{\mathrm{a}}$ & $3^{\text {th }}$ & $248-308$ & $288.67 \pm 38.11^{\mathrm{c}}$ & $2^{\text {nd }}$ & $357-413$ & $367.33 \pm 33.13^{\mathrm{a}}$ & $3^{\text {sd }}$ \\
\hline $\mathrm{D} 2\left(0.5 \mathrm{gkg}^{-1}\right)$ & $\begin{array}{c}178-233 \\
35-51\end{array}$ & $\begin{array}{c}206.50 \pm 27.54^{\mathrm{b}} \\
42.75 \pm 7.10\end{array}$ & $6^{\text {th }}$ & $145-199$ & $173.33 \pm 27.10^{b}$ & $3^{\text {th }}$ & $\begin{array}{c}319-408 \\
69-888\end{array}$ & $\begin{array}{c}352.48 \pm 48.57^{\mathrm{a}} \\
76.98 \pm 10.02\end{array}$ & $\begin{array}{l}2^{\text {nd }} \\
4^{\text {th }}\end{array}$ \\
\hline D3 $\left(1.0 \mathrm{gkg}^{-1}\right)$ & - & - & - & $73-98$ & $85.67 \pm 12.50^{\mathrm{a}}$ & $5^{\text {th }}$ & $321-386$ & $358.00 \pm 33.42^{\mathrm{a}}$ & $3^{\text {rd }}$ \\
\hline $\mathrm{D} 4\left(2.0 \mathrm{gkg}^{-1}\right)$ & - & - & - & - & - & - & $\begin{array}{c}302-374 \\
67-75\end{array}$ & $\begin{array}{c}341.67 \pm 37.51^{\mathrm{a}} \\
70.33 \pm 4.16^{\mathrm{a}}\end{array}$ & $3^{\text {rd }}$ \\
\hline D5 $\left(4.0 \mathrm{gkg}^{-1}\right)$ & - & - & - & - & - & - & $\begin{array}{c}286-377 \\
52-83\end{array}$ & $\begin{array}{l}337.33 \pm 46.61 \\
67.33 \pm 15.50^{\mathrm{a}}\end{array}$ & $\begin{array}{l}2^{\text {nd }} \\
3^{\text {rd }}\end{array}$ \\
\hline $\mathrm{D} 6\left(8.0 \mathrm{gkg}^{-1}\right)$ & _. & _. & - & _. & _. & _. & $311-359$ & $333.00 \pm 24.25^{\mathrm{a}}$ & $4^{\text {th }}$ \\
\hline
\end{tabular}

$n=3$. Values in each column with the same superscript are not significantly different $(p>0.05)$.

Table 3: Some Physico-chemical Parameters of water in tanks used to culture Oreochromis niloticus fed crude extract of the three plants

\begin{tabular}{llllllllll}
\hline & DO $(\mathrm{mg} L)$ & Temp. $\left.{ }^{\circ} \mathrm{C}\right)$ & $\mathrm{pH}$ & & & & & \\
\hline D1 $\left(0.0 \mathrm{gkg}^{-1}\right)$ & $5.63 \pm 0.25^{\mathrm{a}}$ & $28.00 \pm 1.00^{\mathrm{a}}$ & $7.51 \pm 0.05^{\mathrm{a}}$ & $5.33 \pm 1.07^{\mathrm{a}}$ & $27.00 \pm 1.00^{\mathrm{a}}$ & $7.51 \pm 0.21^{\mathrm{a}}$ & $5.60 \pm 0.65^{\mathrm{a}}$ & $27.50 \pm 0.50^{\mathrm{a}}$ & $7.42 \pm 0.25^{\mathrm{a}}$ \\
D2 $\left(0.5 \mathrm{gkg}^{-1}\right)$ & $5.58 \pm 1.06^{\mathrm{a}}$ & $28.50 \pm 0.50^{\mathrm{a}}$ & $7.62 \pm 0.28^{\mathrm{a}}$ & $5.17 \pm 0.57^{\mathrm{a}}$ & $28.33 \pm 0.58^{\mathrm{a}}$ & $7.48 \pm 0.08^{\mathrm{a}}$ & $5.45 \pm 0.49^{\mathrm{a}}$ & $27.17 \pm 0.76^{\mathrm{a}}$ & $7.54 \pm 0.05^{\mathrm{b}}$ \\
D3 $\left(1.0 \mathrm{gkg}^{-1}\right)$ & $5.40 \pm 0.30^{\mathrm{a}}$ & $27.00 \pm 1.00^{\mathrm{a}}$ & $7.59 \pm 0.10^{\mathrm{a}}$ & $4.99 \pm 0.59^{\mathrm{a}}$ & $28.17 \pm 0.76^{\mathrm{a}}$ & $7.50 \pm 0.04^{\mathrm{ab}}$ & $5.38 \pm 0.33^{\mathrm{a}}$ & $28.00 \pm 1.00^{\mathrm{a}}$ & $7.58 \pm 0.02^{\mathrm{b}}$ \\
D4 $\left(2.0 \mathrm{gkg}^{-1}\right)$ & $5.37 \pm 0.30^{\mathrm{a}}$ & $27.5 \pm 0.50^{\mathrm{a}}$ & $7.58 \pm 0.07^{\mathrm{a}}$ & $5.40 \pm 0.50^{\mathrm{a}}$ & $27.33 \pm 0.58^{\mathrm{a}}$ & $7.46 \pm 0.01^{\mathrm{a}}$ & $5.25 \pm 0.05^{\mathrm{a}}$ & $28.33 \pm 0.58^{\mathrm{a}}$ & $7.61 \pm 0.08^{\mathrm{b}}$ \\
D5 $\left(4.0 \mathrm{gkg}^{-1}\right)$ & $5.65 \pm 0.25^{\mathrm{a}}$ & $28.00 \pm 1.53^{\mathrm{a}}$ & $7.62 .0 .22^{\mathrm{a}}$ & $5.75 \pm 0.76^{\mathrm{a}}$ & $28.33 \pm 1.57^{\mathrm{a}}$ & $7.58 \pm 0.06^{\mathrm{ab}}$ & $5.49 \pm 0.07^{\mathrm{a}}$ & $28.50 \pm 0.50^{\mathrm{a}}$ & $7.59 \pm 0.15^{\mathrm{b}}$ \\
D6 $\left(8.0 \mathrm{gkg}^{-1}\right)$ & $5.00 \pm 0.06^{\mathrm{a}}$ & $27.50 \pm 0.5^{\mathrm{a}}$ & $7.70 \pm 0.05^{\mathrm{a}}$ & $5.50 \pm 0.43^{\mathrm{a}}$ & $27.00 \pm 1.00^{\mathrm{a}}$ & $7.69 \pm 0.04^{\mathrm{c}}$ & $5.70 \pm 0.23^{\mathrm{a}}$ & $27.33 \pm 0.58^{\mathrm{a}}$ & $7.60 \pm 0.03^{\mathrm{b}}$ \\
\hline
\end{tabular}

$n=3$. Values in each column with the same superscript are not significantly different $(p>0.05)$

\section{Discussion}

The crude leaf extracts of $A$. indica and $M$. indica leaf significantly inhibited prolific breeding in $O$. niloticus. The varying concentrations of crude extract of $A$. indica leaf resulted in the reduction of hatchlings count in 0 . niloticus fed $0.5 \mathrm{~g} / \mathrm{kg}$ diet while no reproduction was observed in groups that were fed $1.0,2.0,4.0$ and $8.0 \mathrm{~g} / \mathrm{kg}$ diets respectively. The varying concentrations of crude extract of $M$. indica leaf also resulted in the decline in the hatchlings count of 0 . niloticus fed 0.5 and 1.0 $\mathrm{g} / \mathrm{kg}$ diets respectively when compared with the control. The result also showed no reproduction in groups fed $2.0,4.0$ and $8.0 \mathrm{~g} / \mathrm{kg}$ diets respectively. This finding is in line with the result of previous study carried out on rats, mice, rabbits and guinea pigs. Deshpande et al., (1980) reported that aqueous extract of crush green leaf caused sterility in mice, rats, rabbits and guinea pigs. Purohit and Dixit, (1991) observed inhibition of spermatogenesis in rat when neem seed oil (petroleum ether extract) at a dose of $0.5 \mathrm{~g} / \mathrm{kg}$ body weight was administered. Shaikh et al., (1993) also observed antifertility effect in male rats when $20-60 \mathrm{mg} / \mathrm{kg}$ dried leaf were administered to male rats for 24 days. Similar result was also observed by Ibraheem, et al., (2007) when $1 \mathrm{~g} / \mathrm{kg}$ of methanolic leaf extract of Mangifera indica leaf was administered to some group of male Sprague Dawley rats that were allowed to mate with untreated female rats. Although Psidium guajava leaf had been reported to possess antifertility properties and its antiimplantation effects had already been observed on rats (Aliyu, 2007; Sri Retno et al., 2008), in the present study the varying concentrations of crude extract of $P$. guajava leaf had no significant effects on the reproduction of $O$. niloticus although slight reduction in the number of hatchlings were observed with no significant difference within the treatments as the concentration levels of crude extract of $P$. guajava leaf 
increased, suggesting that at much higher level of concentrations, $P$. guajava may be effective at controlling prolific breeding in 0 . niloticus.

Recent studies showed that saponins a glycoside and one of the active photochemical substance present in most plants was responsible for the antifertility effect observed when it was incorporated into feed and fed to tilapia (Mohammed, 1996; Luckstadt et al., 2006; Kuhlmann et al., 2006; Obaroh et al., 2012). Earlier worker reported high concentration of alkaloids, saponins and tannins in $A$. indica, M. indica and P. guajava (Atangwho et al., 2009; Aiyelaagbe and Osamudiamen 2009; Uboh et al., 2010). Variation was observed in the dissolved oxygen, temperature and $\mathrm{pH}$ in all the treatments but no significant difference ( $p>0.05)$ except in the $\mathrm{pH}$ of water in tanks containing fish fed varying concentration of crude extracts of $M$. indica and $P$. guajava leaf. The water parameters were however within the acceptable range for tilapia culture as reported by Ross, (2000). There was no mortality during the course of this study.

\section{Conclusion}

This study is an attempt to investigate the effects of crude extracts of $A$. indica, $M$. indica and $P$. guajava leaf on reproduction of $O$. niloticus. This study infers that, for efficient and sustainable development of tilapia culture, ethanolic crude extracts of Azadirachta indica and Mangifera indica leaf could effectively be used to control prolific breeding in Oreochromis niloticus.

\section{References}

Aiyelaagbe, O. O. and Osamudiamen, P. M. (2009). Phytochemical screening for active compounds in Mangifera indica leaves from I badan, Oyo state. Plant Sciences Research. 2(1): 11-13.

Aliyu, B. S. (2007). Some Ethno-medicinal Plants of the Savanna Region of West Africa: Description and Phytochemicals. Triumph Publishing Company Limited, Gidan Sa'adu Zungur, Kano. 200p.

Atangwho, I. J., Ebong, P. E., Eyong, E. U., Williams, I. O., Eteng, M. U. and Egbung, G. E. (2009). Comparative chemical composition of leaves of some antidiabetics medicinal plants: Azadirachta indica, Veronia amygdalina and Gongronema latifolium. African Journal of Biotechnology. 8(18): 4685-4689.

Ayensu, E. S. (1978). Medicinal plants of West Africa. Reference Publication, Algonac, Michigan. Pp 4549.

Balarin, J. D. and Hatton, J.P. (1979). Tilapia: A guide to their biology and culture in Africa. University of Sterling Scotland. Pp 48-56.

Bodharkar, S. L., Garg, S. K. and Mathur, V. S. (1974). Effect of five indigenous plants on early pregnancy in female albino rats. Journal of Medical Research. 62 (6): 831-837.

Bokhari, M. H. and Aslam, K. M. (1985). Neem (Melia Azadirachta A. Juss). A useful tree in Northern Nigeria. Annals of Borno. II: 83-86.

Boyd, C. E. (1981). Water quality in warm water fish pond. Craftmasters Printers, Inc., Opelika. 369 pp.

Dada, A. and Ikuerowo, M. (2009). Effects of ethanolic extracts of Garcinia kola on growth and haematology of catfish (Clarias gariepinus) broodstock. African Journal of Agricultural Research. 4 (4): 344-347.

Deshpande, V. K., Mendulkar, K. N. and Sadre, N. L. (1980). Male infertility activity of Azadirachta indica in mice. J ournal of Postgraduate Medicine. 26: 167-170.

Dixit, V. P., Jain, P. and Purohit, A. K. (1992). Medicinal uses of neem (Azadirachta indica) in fertility regulations diabetes and atherosclerosis. Recent Advance in Medical and Aromatic Spice Crops. 2, 463-471.

Ekanem, S. B and Okoronkwo, T. E. (2003). Paw paw seed as fertility control agent on male Nile tilapia. NAGA Worldfish Center Newletter. 26 (2). 8-10.

Goonasekera, M. M, Gunawardana, V. K., Jayasena, K., Mohammed, S. G., Balasubramaniam, S. (1995). Pregnancy terminating effect of Jatropa curcas in rats. Journal of Ethnophamacology. 47 (3): 117123. 
Ibraheem, S. O., Olatunji-Bello, I. I. and Awobajo, F. O. (2007). Anti-fertility effect of methanolic leaf extract of Mangifera indica (mango leaves) on male Sprague Dawley rats. The Federation of American Society and Experimental Biology Journal. 21:103-107.

Khillare, B. and T. C. Shrivastav (2003). Spermicidal activity of Azadirachta indica neem leaf extract. Contraception 68, 225-229.

Kuhlmann, M., Y. Primavera-Tirol, C. Luckstadt, R. Ampoyos, R. Remetio and Pastrana E. (2006). Effects of Quillaja saponins supplementation on growth performance and reproduction activity of saline tolerant Tilapia (Oreochromis niloticus). Proceedings of the $7^{\text {th }} /$ nternational Symposium on fish Nutrition and Feeding, Biarritz, France. Pp 156-158.

Lohiya, N. K. and Goyal, R. B. (1992). Antispermatogenic effects of tolnidamine in Langur (Presbytis entellus). Indian Journal of Experimental Biology. 30(11): 1051-1055.

Luckstadt, C. P. Kuhlmann and Y. Primavera-Tirol. (2006). Benefits of saponin supplementation to tilapia. Feed Mix. 14 (5): 22-23.

Mair, G. C and D. C Little (1991). Population Control in farm tilapia. NAGA /CLARM Quarterly. 17(4): 610.

McNeil, R.T, C.C Noronha, J.O Kesumiju and A.O. Okanlawon (2003). The anti ovulatory effect of seed extracts of Ricinus communus Linn. Nigerian Journal of Health and Biomedical Science. 2 (1): 3134.

Mohammed, S. D. S (1996). A review of plants with antifertility activity. Journal of Medicinal and Aromatic Plant Science. 18, 276-279.

Musa, K. Y, A. Ahmed, H. Ibrahim, G. Arowosaiye and O. S. Olonitola (2000). Phytochemical and antimicrobial studies of leaves of Acalypha racemosa. Nigerian Journal of Natural Products and Medicine. 4, 67-69.

Obaroh, I.O. and Achionye-Nzeh, G.C. (2010). Effect of Mangifera indica Leaves Extract on Growth Response of Oreochromis niloticus. Journal of Biological Sciences and Bioconservation. Vol 2, 5762.

Obaroh, I. O., Nzeh, G. C and Oguntoye, S. O. (2012). Control of Reproduction in Oreochromis niloticus (L) Using Crude Extract of Azadirachta indica Saponin. Advances in Environmental Biology. 6 (4): 1353-1356.

Obaroh, I. O. and Achionye-Nzeh, G. C. (2011). Effects of Crude Extract of Azadirachta indica Leaves at Controlling Prolific Breeding in Oreochromis niloticus (Linnaeus, 1758). Asian J ournal of Agricultural Research 5 (5): 277-282.

Obaroh, I. O., Nzeh, G. C and Oguntoye, S. O. (2012). Control of Reproduction in Oreochromis niloticus (L) Using Crude Extract of Azadirachta indica Saponin. Advances in Environmental Biology. 6 (4): 1353-1356.

Purohit, A and Daradka, H. M. M. (1999). Effect of fixed oil of Nigella sativa on male fertility in normal and hyperlipidemic rats. Indian Drugs 36 (2): 260-262.

Purohit, A. and Dixit, V. P. (1991). A review on medicinal plants exhibiting antifertility activity in males. Neem Newsletter. 8 (2): 13-14.

Ridha, M. T. (2006). Tilapia Culture in Kuwait: Constrains and Solutions. NAGA International Center for Living Aquatic Resources Management Quarterly. 29 (3-4):71-73.

Ross, L. G. (2000). Environmental physiology and energetic. In Tilapia: biology and exploitation (Editors, M. C. M. Beveridge and B. J. McAndrew) Kluwer Academic Publishers. UK. Pp 89-128.

Shaikh, P .D., Manivannan, B., Patham, K. M., Kastrim, M. And Ahmed, R. N. (1993). Antispermatic activity of Azadirachta indica leaves in albino rats. Current Science. 64 (9): 688-689.

Sri Retno, D. A., Endang, S. , Elfi, V. H. S. and Setiyani, S. (2008). Activity test of guava (Psidium guajava) leaf methanol extract as contraception antifertility to white mice (Rattus norvegicus). Indian Journal of Chemistry, 8 (2): 23-26.

Uboh, F. E., Okon, I. E. and Ekong, M. B. (2010). Effect of aqueous extract of Psidium guajava leaves on liver, enzyme, histological integrity and haematological indices in rats. Gastroenterology Research. 3 (1): $32-38$. 